UDC 37.091.12 [37.091.12.011.3-051:81'243]

DOI https://doi.org/10.24919/2308-4863/41-2-16

\title{
Olga KRSEK,
}

orcid.org/0000-0003-2218-9548

Doctor in Education, Assistant professor,

Head of Foreign Languages and Professional Communication Department

Volodymyr Dahl East Ukrainian National University

(Severodonetsk, Luhansk region, Ukraine)krsek@snu.edu.ua

Tetyana MODESTOVA, orcid.org/0000-0002-7345-4586

Doctor in Education, Assistant professor, Associate Professor at the Department of Foreign Languages and Professional Communication Volodymyr Dahl East Ukrainian National University (Severodonetsk, Luhansk region, Ukraine) modestova@snu.edu.ua

\author{
Lina BIELOVETSKA, \\ orcid.org/0000-0003-3360-687X \\ PhD in Education,
}

Senior Lecturer at the Department of Foreign Languages and Professional Communication Volodymyr Dahl East Ukrainian National University (Severodonetsk, Luhansk region, Ukraine) bielovetska_l@snu.edu.ua

\section{CURRENT ISSUES IN THE TRAINING OF FOREIGN LANGUAGE TEACHERS FOR PROFESSIONAL ACTIVITIES}

\begin{abstract}
The article reviews studies that focus on the main principles of the training of foreign language teachers for professional activities. The text addresses the theme of teachers' professional development. The aim of the research is to theoretically substantiate the current issues of the training of foreign language teachers for professional activities. The factors that significantly influence teachers' professional development are identified. It is stressed that foreign language teachers need the knowledge and skills to be flexible and reflective professionals who respond to the needs of 21st-century students. A professionally oriented approach to learning a foreign language that involves building students 'ability in foreign language communication within specific academic situations is considered as well. Professional activity of foreign language teachers is shown as the production of socially significant goods or services in the public sphere. The study is based on generalization of a set of competences of foreign language teachers for their professional activities: cultural and linguistic competences, linguistic and didactic competences, social and educational competences, professional and educational competences. This study is aimed to explore how the foreign language teachers develop their professionalism particularly in terms of professional competencies. The components of the professional competence of a foreign language teacher: methodological, psychological, pedagogical, socio-psychological, linguistic, socio-cultural are considered as an inseparable unity of the foreign language teachers professional activities. The typical modes of professional development is shown (individual reading/study/research; study groups among peers focused on a shared need or topic; observation; coaching; mentoring of new educators by more experienced colleagues; team meetings to learn a new strategy; online courses; conferences.
\end{abstract}

Key words: foreign language teachers, professional activities, competencies, professional development.

Ольга КРСЕК, orcid.org/0000-0003-2218-9548 доктор педагогічних наук, доцент, завідувач кафедри іноземних мов та професійної комунікації Східноукраӥнського національного університету імені Володимира Даля (Сєвєродонеиьк, Луганська область, Україна) krsek@snu.edu.иа

Тетяна МОДЕСТОВА, orcid.org/0000-0002-7345-4586 доктор педагогічних наук, доцент,

професор кафедри іноземних мов та професійної комунікації Східноукраӥнського національного університету імені Володимира Даля (Сєвєродонецьк, Луганська область, Україна) modestova@snu.edu.иа 
Ліна БСЛОВЕЦЬКА,

orcid.org/0000-0003-3360-687X кандидат педагогічних наук, стариий викладач кафедри іноземних мов та професійної комунікаиї Східноукраїнського національного університету імені Володимира Даля (Сєвєродонеиьк, Луганська область, Украӥна) bielovetska_l@snu.edu.иа

\title{
АКТУАЛЬНІ ПРОБЛЕМИ ПІДГОТОВКИ ВИКЛАДАЧІВ ІНОЗЕМНОЇ МОВИ ДО ПРОФЕСІЙНОЇ ДІЯЛЬНОСТІ
}

\begin{abstract}
Устаттірозглядаютьсядослідження, присвяченіосновнимпринщипампідготовкивикладачівіноземноїмовидо професійної діяльності. У тексті порушується питання професійного розвитку викладачів. Метою дослідження є теоретичне обтрунтування актуальних питань підготовки викладачів іноземної мови до професійної діяльності. Виявлено фактори, щзо суттєво впливають на професійний розвиток викладачів. Підкреслюється, щзо викладачам іноземних мов необхідні знання і навички, щзоб бути гнучкими і рефлексивними професіоналами, які відповідають потребам студентів 21 століття. Також розглядається професійно орієнтований підхід до вивчення іноземної мови, який передбачає розвиток у студентів здатності до іншомовного спілкування в конкретних навчальних ситуаціях. Професійна діяльність викладачів іноземної мови проявляється як виробництво сочіально значущих послуг у громадській сфері. Дослідження засноване на узагальненні набору компетенцій викладачів іноземноі мови для професійної діяльності (культурологічні, лінгвістичні, дидактичні, соціальні, освітні, професійні). Це дослідження спрямоване на вивчення того, як викладачі іноземної мови розвивають свій професіоналізм, особливо з точки зору професійних компетениій. Компоненти професійної компетентності викладача іноземноі мови: методологічні, психолого-педагогічні, сочіально-психологічні, лінгвістичні, сочіокультурні розглядаються як нерозривна єдність професійної діяльності вчителя іноземної мови. Показані типові способи професійного розвитку (індивідуальне читання/ вивчення/ дослідження; навчальні групи серед однолітків, зосереджені на загальній потребі або темі; спостереження; коучинг; наставництво нових викладачів більш досвідченими колегами; командні зустрічі для вивчення нової стратегії; онлайн-курси; конферениії.
\end{abstract}

Ключові слова: викладачі іноземних мов, професійна діяльність, компетениії, професійний розвиток.

Statement of the problem in general aspect. The main principle of the training of foreign language teachers for professional activities is the comprehensive development of a professionally competent person, active, ready to assume responsibility. Qualitative growth of a specialist's competence strengthens his competitiveness, which is significant in modern conditions, when the social need for a professional initiative is growing. This means that the reproductive and creative nature of the teacher's attitude to the professional activity becomes more valuable. Along with special training, higher education is designed to form a spiritually rich, intellectually developed, value-oriented personality, who is able to act and create according to the laws of beauty and goodness. The urgency of the problem raised in the article is explained by the increasing demand for qualified specialists who have a good command of a foreign language in the professional activities.

The analysis of recent research and publications. There has been a great interest recently in the discussion of teachers and their professional development, the training of foreign language teachers for professional activities by several researchers, educational practitioners, and teachers (Bamfield A., Chan G., Davidson G., Dunlop F., Hicks D., Kennedy L., Littlejohn A., Philips T., Soriano D., Qing X. The required competencies, foreign language teachers must pos- sess for professional activities, are considered by Brown G., Canale M., Chomsky N., Grigorieva Ye., Hymes D., Karpova L., Khakimova D., Ladonina Ye., Malmkjaer K., Popova O., Shchekoldina A., Swain M. Williams J.

The aim of the research is to theoretically substantiate the current issues of the training of foreign language teachers for professional activities.

Main material presentation. In today's world teachers need to constantly innovate and adapt. Supported by professional development, they need the knowledge and skills to be flexible and reflective professionals who respond to the needs of 21 st-century students. The best learning outcomes depend on high-quality teaching and training. Knowing how to develop professional skills efficiently and appropriately is the key to success for teachers and the institutions they teach in. The higher professional education mission is to develop specific professional skills required in the future activities of the university graduates. A professionally oriented approach to learning a foreign language involves building students' ability in foreign language communication within specific professional, business, academic situations taking into account the characteristics of professional thinking and application of knowledge.

Professional activity of foreign language teachers - is the production of socially significant goods 
or services in the public sphere. Professional can be called the sphere of socially oriented, purposeful activity. Professional activity - an area of competence, which is limited in scope. Professional activity - a certain stage in the development of a specialist in the subject field. A modern professionally oriented approach to teaching a foreign language assumes forming students' foreign language communicative ability, in particular professional, business, scientific environments and situations, while taking into consideration professional thinking peculiarities and arrangement of motivational, stimulating and research oriented activity.

The higher professional education mission is to develop specific professional skills required in the future activities of the university graduates. A professionally oriented approach to learning a foreign language involves building students' ability in foreign language communication within specific professional, business, academic situations taking into account the characteristics of professional thinking and application of knowledge. The professional component of the foreign language communicative competence is composed of a set of professional competences that a graduate must have. Such professional competences as cultural and linguistic competences, linguistic and didactic competences, social and educational competences, professional and educational competences are particularly relevant for training future foreign language teachers (Karpova, Grigorieva et al, 2018: 5).

The professional component of the foreign language communicative competence is composed of a set of professional competences that a graduate must have. Such professional competences as cultural and linguistic competences, linguistic and didactic competences, social and educational competences, professional and educational competences are particularly relevant for training future foreign language teachers. Thus, all these components comprise the foreign language teachers' professional competence and should be taken into consideration while planning and selecting the content for practical foreign language classes.

Teachers' quality plays a paramount role in the improvement of quality of education. A way to ensure high quality teachers is through effective continuous professional development for teachers. This present study is aimed to explore how the foreign language teachers develop their professionalism particularly in terms of pedagogical and professional competencies.

The professional competence of the teacher of a foreign language is an inseparable unity of the content and structural components, the totality of knowledge, skills, abilities and abilities realized through the psychological, pedagogical, methodical, com- municative, philological, general cultural, information, social and managerial competences. G. Kitaygorodskaya singles out the following components of the professional competence of a foreign language teacher: methodological competence; psychological and pedagogical competence; socio-psychological competence; linguistic and sociocultural competence; pedagogical skills; professional reflection. A number of documents of the European Union attempted to define a set of competencies that would characterize the activities of the teacher. Among them were singled out: the ability to live in a multicultural, tolerant society; the ability to coordinate their lifestyle with environmental objectives; the implementation of life in the context of European citizenship; maintenance of gender equality in the family, in the workplace, in social relations; the development of creativity and innovation, the possession of information technology and others (Khakimova D, 2020: 66).

Competence is a totality of interrelated qualities of a person (knowledge, skills, experience, command of methods of working), assigned with respect to a certain sphere of objects and processes and necessary for efficient and productive activity in respect to them (Hymes, 1972: 67).

Level of competence refers to the possession of a relevant competence including a personal attitude towards it and towards the object of activity. Competence is understood as a requirement (norm) relation to the standard of achievement of a pupil and Level of Competence is understood as his personal quality or totality of qualities and a minimum experience in the relevant activity. A level of competence achieved is always something which has a personal dimension to it, which is reflected in a pupil's personal qualities (Canale, Swain, 1983: 122).

In recent investigations the following functions of competence and level of competence in relation to the personality of a learner are singled out: reflect and develop personal relevance to a learner of the of the objects under study; characterize the personal component of a learner's education, the degree of his abilities and practical skills; set a minimum standard of experience in practical activities; develop possibilities of solving real problems in everyday life from common problems to professional and social ones; they are many-dimensional - they certain to all the basic groups of personal qualities of a learner to be developed ; represent integral characteristics of the quality of learners' training; in the aggregate, they determine and reflect the functional competence of a pupil (Brown, Malmkjaer, Williams, 1996: 25-34).

The competence includes long-term readiness as an integrative personal education that includes moti- 
vational, emotional-volitional, behavioral and assessment components along with cognitive and behavioral aspects, that is, knowledge, skills and skills. This allows you to define competencies as "readiness and ability". Readiness can be correlated with longterm readiness as an integrative personal education, including motivational, emotionally strong-willed, behavioral and evaluation components. The ability is correlated with cognitive and behavioral aspects. This implies knowing the content of competence and experience of manifestation of competence in a variety of situations (Khakimova D, 2020: 67).

Educational competence is a totality of interconnected semantic orientations, knowledge, skills and learners' experience which are necessary for performing personally and socially relevant productive activities in relation to the objects of reality (Littlewood, 1981: 33). S. Brumfit in the work "Communicative Methodology in Language Teaching: defines communicative competence as an ability to solve by means of foreign language communicative problems important for an individual and for society, arising in the everyday, educational, professional or cultural spheres of life. It is an ability to realize linguistic competence in different situations of communication. (Brumfit,1957: 80); linguistic competence as possession of a system of information and knowledge about the foreign language pertaining to its levels (phonetics, grammar etc.) as well as an ability to use this knowledge in practice. The linguistics aspects of communicative competence are those that have to do with achieving an internalized functional knowledge of the elements and structures of the language (Brumfit, 1957: 48).

Functional competence refers to the ability to accomplish communication purposes in a language. There are a number of different kinds of purposes for which people commonly use language (Stempleski, Tomalin, 1990: 105).

Cultural competence is a totality of knowledge about the country of the foreign language. Such knowledge provides the learner with a certain level of skills and experience in using national-cultural component of the language, speech etiquette and non-verbal means of communication. Cultural competence is the ability to understand behavior from the standpoint of the members of a culture and and to behave in a way that would be understood by the members of the culture in the intended way. Cultural competence therefore involves understanding all aspects of a culture, but particularly the social structure, the values and beliefs of the people, and the way things are assumed to be done (Cooper, Lavery, Rinvolucri, 1993: 148).
Some more competences are selected by R. Cooper, M. Lavery and M. Rinvolucri: linguo-cultural competence is knowledge of national customs, traditions, features of the country of in question; an ability to extract culturally relevant information from units of the language and an ability to use this information to achieve effective communication (Cooper, Lavery, Rinvolucri, 1993: 149).

Strategic Competence (compensatory competence) is an ability to fill gaps in the knowledge of the language, speech and social experience during the process of communication in foreign language (Bamfield, Littlejohn, Hicks, 1997: 64).

Social Competence is an ability to have communicated successfully with other people. A wish for entering communication is explained by the presence of need, motives, a definite attitude toward the future partners of communication and personal experience. An ability to enter communication requires an ability to behave adequately in a social situation and to manage it (Bamfield, Littlejohn, Hicks, 1997: 73).

Socio Cultural Competence means familiarity of students with national cultural specific features of linguistic behavior and an ability to use those components of socio - cultural context. That are relevant for production and perception of speech from native speakers' point of view: customs, rules, norms, social conventions, rituals, social stereotypes, knowledge of regional geography etc (Kelly, 1992: 52).

Sociolinguistic competence is the ability to interpret the social meaning of the choice of linguistic varieties and to use language with the appropriate social meaning for the communication situation (Geddes, 1997: 74).

Interactional competence involves knowing and using the mostly-unwritten rules for interaction in various communication situations within a given speech community and culture. It includes, among other things, knowing how to initiate and manage conversations and negotiate meaning with other people. It also includes knowing what sorts of body language, eye contact, and proximity to other people are appropriate, and acting accordingly (The Intensive English Course, 1996: 3).

L. Karpova, Ye. Grigorieva, Ye. Ladonina, O. Popova, A. Shchekoldina state that developing the skills to give precise and correct instruction and explanation in the foreign language in professionally oriented situations, future teachers adopt appropriate linguistic means (core lexis, grammar constructions and speech patterns). For example, they are given two concepts - Teacher Training и Teacher Development - to become familiar with and then to discuss (Karpova, Grigorieva et al, 2018: 4). 
According to N. Ramadhani, D. Ancok, Y. Swasono, and P. Suryanto, qualified teachers are those who show a high commitment to their profession as teachers. The teachers are required to have ability to take the initiative and be innovative in inventing media of learning, must have ability to communicate clearly and pleasantly, should be able to facilitate learning process which involve planning effectively, establishing rules that are reasonable and not excessive in number, and arranging the classroom so that instructions go smoothly (Ramadhani, Ancok 2 et al, 2012: 38).

Teachers are 'at the front line of education delivery, and they face the increasing weight of demands and expectations. It's obvious that good teachers are better at teaching students effectively. When teachers have access to continuous learning opportunities and professional development resources, they're better equipped to become good teachers - especially if their students have learning needs or are performing below or above grade level. The typical modes of professional development have been shown by Hayes Mizell. He's distinguished:

- Individual reading/study/research.

- Study groups among peers focused on a shared need or topic.

- Observation: teachers observing other teachers.

- Coaching: an expert teacher coaching one or more colleagues.

- Mentoring of new educators by more experienced colleagues.

- Team meetings to plan lessons, problem solve, improve performance, and/or learn a new strategy.

- Faculty, grade-level, or departmental meetings.

- Online courses.

- College/university courses.

- Workshops to dig deeper into a subject.

- Conferences to learn from a variety of expertise from around the state or country.

- Whole-school improvement programs.

- Proprietary programs by private vendors (Mizell, 2010: 5).

Self-reflection is a critical skill for the ongoing development of one's professional practice. Many effective teachers use three levels of reflection: reflection on action, reflection for action and reflection in action. Self-reflection can be broken down into the following four steps: 1) problem identification, during which teachers identify a problem or question about their practice that they are motivated to address; 2) information gathering, during which teachers collect data to inform the area of practice; 3) reflection and decision-making, during which teachers attempt to find meaning in the data through reflection and analysis; and 4) application and change, during which teachers plan how to improve their practice. Self-reflection can be combined with other PD strategies such as action research, journalling and developing a professional portfolio.

Professional development yields three levels of results: (a) educators learn new knowledge and skills because of their participation; (b) educators use what they learn to improve teaching and leadership; and (c) student learning and achievement increase because educators use what they learned in professional development. Th e results of professional development can be assessed through techniques such as surveys, tests, observations, video recordings, and interviews. If administrators become better leaders and teachers become more eff ective and apply what they learn so that students achieve at higher levels, professional development is worth the cost (Mizell, 2010: 16).

Conclusion. Professional activities of foreign language teachers provides ongoing opportunities for educators to continue to improve their knowledge and skills so they can help students achieve. When educators learn, students learn more. Anyone concerned about their students' futures will want to support a cycle of continuous professional growth for educators. Important personal qualities for English teachers include knowledgeable about the subject matter, accessible, can build caring relationships with students, fair and respectful, and passionate. Professional development in the 21 st century is important to the growth and development of the contemporary educator. Today's educational realm is full of multiple perspectives, technologies, and opportunities for students and educational leaders. The goal of professional development for educators is to go beyond maintenance and to create sustainability and professional longevity. For foreign language teachers, effective professional activities in the 21 st century come from finding ways to enhance teaching and learning strategies.

\section{BIBLIOGRAPHY}

1. Bamfield A., Littlejohn A., Hicks D. Welcome to English Video. Cambridge UP, 1997. - pp. 64-73.

2. Brown G., Malmkjaer K., Williams J. Performance and competence in Second Language Acquisition.- Cambridge University Press, 1996. - pp. 25-34. $88 \mathrm{p}$.

3. Brumfit S. Communicative Methodology in Language Teaching - Cambridge, Cambridge University Press, 1984 -

4. Canale M., Swain M. From communicative competence to communicative language pedagogy. Language and Communication. London: Longman, 1983. - 122 p. 
5. Chomsky N. Syntactic structure. New York, 1957.- 80 p. Widdowson H.G. Aspects of Language Teaching.-Oxford: Oxford University Press, 1990. - 218-260 p.

6. Chan, G. The Professional Development of Pre service Teachers in a Postgraduate Diploma in Education Program. Practice and Theory in Systems of Education, 6(2), 2011. - 185-196 pp.

7. Cooper R., Lavery M. and Rinvolucri M. Video. Oxford University Press. 1993. - pp. 145-149.

8. Davidson G., Dunlop F., Soriano. D H., Kennedy L., Philips. T. Going forward: Continuing Professional Development for English Language Teachers in the UK. British Council. 2012. - 18-19 pp.

9. Geddes M. Video in the language classroom. London, Heinemann Educational Books, 1997. - pp. 74-81

10. Hymes D. On communicative competens. In: J. B. Pride and J. Holmes.S ociolinguistics-Middlesex: Penguin Books LTD, 1972.- $67 \mathrm{p}$.

11. The Intensive English Course. A Challenging Program for Serious Students/ Intensive English Programs.- London, 1996. - pp. 2-3

12. Karpova L., Grigorieva Ye., Ladonina Ye., Popova O., Shchekoldina A. Building Professional Competences of English Language Teachers/ SHS Web of Conferences 50, 01077 (2018), pp. 2-5.

13. Kelly R. Video and language learning, an approach to viewing comprehention. RELC Journal, 1992. - pp. 52-57.

14. Khakimova D. Professional competence of the foreign language teacher/ "Problems of Modern Sience and Education", 2020, Nr 1(146), pp. 65-67.

15. Littlewood W. Communicative Language Teaching. An Introduction. - Cambridge, Cambridge University Press, $1981-33 \mathrm{p}$.

16. Mizell $\mathrm{H}$. Why professional development matters/ Learning Forward www.learningforward.org the United States of America, 2010. - pp. 9-25.

17. Stempleski S., Tomalin B. Video in action. Prentice Hale International ELT, 1990. - 105 p.

18. Ramadhani N., Ancok D., Swasono Y., Suryanto P. 2012. Teacher Quality Improvement Program: Empowering Teachers to Increasing a Quality of Indonesian's Education. Proceeding of International Conference on Education and Educational Psychology. Istanbul, Turki. 10-13 October 2012, pp. 38-48.

19. Qing, X. Reflective Teaching: an Effective Path for EFL Teacher's Professional Development. Canadian Social Science, 5(2), 2009. - 35-40 pp.

\section{REFERENCES}

1. Bamfield A., Littlejohn A., Hicks D. Welcome to English Video. Cambridge UP, 1997. - pp. 64-73.

2. Brown G., Malmkjaer K., Williams J. Performance and competence in Second Language Acquisition.- Cambridge University Press, 1996. - pp. 25-34.

3. Brumfit S. Communicative Methodology in Language Teaching - Cambridge, Cambridge University Press, 1984 $88 \mathrm{p}$.

4. Canale M., Swain M. From communicative competence to communicative language pedagogy. Language and Communication. London: Longman, 1983. - $122 \mathrm{p}$.

5. Chomsky N. Syntactic structure. New York, 1957.- 80 p. Widdowson H.G. Aspects of Language Teaching.-Oxford: Oxford University Press, 1990. - 218-260 p.

6. Chan, G. The Professional Development of Pre service Teachers in a Postgraduate Diploma in Education Program. Practice and Theory in Systems of Education, 6(2), 2011. - 185-196 pp.

7. Cooper R., Lavery M. and Rinvolucri M. Video. Oxford University Press. 1993. - pp. 145-149.

8. Davidson G., Dunlop F., Soriano. D H., Kennedy L., Philips. T. Going forward: Continuing Professional Development for English Language Teachers in the UK. British Council. 2012. - 18-19 pp.

9. Geddes M. Video in the language classroom. London, Heinemann Educational Books, 1997. - pp. 74-81

10. Hymes D. On communicative competens. In: J. B. Pride and J. Holmes.S ociolinguistics-Middlesex: Penguin Books LTD, 1972.- $67 \mathrm{p}$.

11. The Intensive English Course. A Challenging Program for Serious Students/ Intensive English Programs.- London, 1996. - pp. 2-3

12. Karpova L., Grigorieva Ye., Ladonina Ye., Popova O., Shchekoldina A. Building Professional Competences of English Language Teachers/ SHS Web of Conferences 50, 01077 (2018), pp. 2-5.

13. Kelly R. Video and language learning, an approach to viewing comprehention. RELC Journal, 1992. - pp. 52-57.

14. Khakimova D. Professional competence of the foreign language teacher/ "Problems of Modern Sience and Education", 2020, Nr 1(146), pp. 65-67.

15. Littlewood W. Communicative Language Teaching. An Introduction. - Cambridge, Cambridge University Press, $1981-33 \mathrm{p}$.

16. Mizell H. Why professional development matters/ Learning Forward www.learningforward.org the United States of America, 2010. - pp. 9-25.

17. Stempleski S., Tomalin B. Video in action. Prentice Hale International ELT, 1990. - 105 p.

18. Ramadhani N., Ancok D., Swasono Y., Suryanto P. 2012. Teacher Quality Improvement Program: Empowering Teachers to Increasing a Quality of Indonesian's Education. Proceeding of International Conference on Education and Educational Psychology. Istanbul, Turki. 10-13 October 2012, pp. 38-48.

19. Qing, X. Reflective Teaching: an Effective Path for EFL Teacher's Professional Development. Canadian Social Science, 5(2), 2009. - 35-40 pp. 